\title{
NOVI KOMPJUTORIZIRANI PROVOZNI POSTUPAK U MEĐUNARODNOM CESTOVNOM PROMETU 4
}

\begin{abstract}
SAŽETAK
Međunarodni cestovni promet obuhvaća prijevoz robe između minimalno dviju država, a uz sam prijevoz obuhvaća i sve popratne komunikacije i operacije (poput ukrcaja, pretovara, iskrcaja, skladištenja, pakiranja i sl.) potrebne da bi se pravodobno izvršio. S ciljem što jednostavnijeg odvijanja međunarodnog cestovnog prometa na području i izvan područja Europske unije uspostavljeni su mnogi bilateralni i multilateralni sporazumi te razne konvencije. No globalizacija tržišta i moderna logistika koja zahtijeva transparentnost cjelokupnog procesa prijevoza tereta dovele su do potrebe automatizacije i informatizacije procedura potrebnih da bi se provoz roba obavio što kvalitetnije uz što manje troškova. Nov kompjutorizirani provozni sustav (NCTS) predstavlja elektronički sustav razmjene podataka koji zamjenjuje papirnu provoznu carinsku deklaraciju na području Europske unije, ali i u razmjeni s trećim državama. Uporaba sustava omogućuje upravljanje carinskim postupcima na svim carinarnicama, upravljanje jamstvima, sustavom naplate, brzo uočavanje i reakciju na eventualne pogreške te povećanje sigurnosti u razmjeni informacija. S ciljem usklađenja s europskim zakonodavstvom u Republici Hrvatskoj razvijena je nacionalna provozna aplikacija koja podržava sve funkcionalnosti NCTS sustava te od kolovoza 2011. omogućuje ostvarenje neprekinutih postupaka provoza robe pod carinskim nadzorom u Republici Hrvatskoj.
\end{abstract}

Ključne riječi: NCTS, konvencije, provozni postupak

\section{UVOD}

Suvremeni međunarodni cestovni prijevoz robe pobuđuje stalni interes sudionika u cestovnom prijevozu robe i traži nove metode i primjenu novih informacijskih tehnologija.

Zbog intenzivnog razvoja cestovnog prometa i složenosti procedura u međunarodnom cestovnom prijevozu robe bilo je potrebno donijeti pravnu regulativu koja podrazumijeva brojne bilateralne i multilateralne sporazume i konvencije.

Brzina, sigurnost i racionalnost cestovnog prijevoza robe unutar europskih i izvaneuropskih zemalja zahtijeva nove oblike dokumentacije i komuniciranja. Sve to nije bilo moguće bez razvoja informatike i interneta.

Osim brzine, sigurnosti i racionalnosti trebalo je posebice razviti sustave koji omogućuju prijevoz robe kroz carinsko područje dviju ili više zemalja. Kako bi se organizirao uspješan prijevoz kroz

Dipl. oec., viši predavač, Veleučilište u Rijeci, Vukovarska 58, 51000 Rijeka, Hrvatska. E-mail: barbara.rudic@veleri.hr

Student, Veleučilište u Rijeci, Vukovarska 58, 51000 Rijeka, Hrvatska. E-mail: antonio.licitar2@gmail.com

Struč. spec. ing. traff., predavač, Veleučilište u Rijeci, Vukovarska 58, 51000 Rijeka, Hrvatska. E-mail: erika.grzin@veleri.hr

Datum primitka rada: 15. 1. 2017.; datum prihvaćanja rada: 1.3. 2017. 
carinsko područje uvode se novi sustavi (poput NCTS sustava) koji ubrzavaju i pojednostavljuju provozne procedure.

Novi kompjutorizirani provozni sustavi zahtijevaju posebnu pozornost stručnjaka i znanstvenika iz područja cestovnog prijevoza. Osim stručnjaka i znanstvenika procedure i dokumentacija traže stalno osposobljavanje svih sudionika u međunarodnom cestovnom prometu.

Istraživanja i analize u ovom radu trebali bi pridonijeti poboljšanju procedura te posebice ubrzanju carinskih i drugih formalnosti oko prijevoza robe u međunarodnom cestovnom prijevozu.

\section{DOKUMENTI I KONVENCIJE U MEĐUNARODNOM CESTOVNOM PRIJEVOZU ROBE}

Međunarodni cestovni prijevoz robe je djelatnost čije je osnovno obilježje prijevoz robe između dviju ili među više država. Osim prijevoza tu su uključene i razne djelatnosti poput utovara, istovara, pretovara, pakiranja, označavanja, sortiranja i sličnih poslova te poslova otpremnika i kontrolnih poslova, bez kojih se cestovni prijevoz ne bi mogao obavljati. S obzirom na to da se cestovni prijevoz nakon II. svjetskog rata počeo intenzivno razvijati, bila je neophodna pravna regulativa, pa su uspostavljeni mnogi bilateralni i multilateralni sporazumi te razne konvencije s ciljem što jednostavnijeg odvijanja cestovnog prometa unutar europskih $\mathrm{i}$ izvaneuropskih zemalja.

Svaka država može propisati i svoja pravila vezana uz obavljanje prijevoza na svom teritoriju, koja moraju biti u skladu s konvencijama, pa ulazak u stranu državu može biti uvjetovan ulaznom dozvolom te zemlje. Za zemlje koje nisu članice Europske unije ulazne dozvole reguliraju se bilateralnim sporazumom s pojedinim članicama Europske unije na načelu godišnjih kvota, a na temelju reciprociteta. Dobivanjem ulazne dozvole za prijevoz kroz ili u određenu zemlju prijevoznik se obvezuje pribaviti sve isprave koje mogu tražiti razni organi te zemlje, ako želi da se transport obavi bez ikakvih poteškoća i nepotrebnih zastoja. Te su isprave potrebne za osoblje, za vozilo te za teret koji se prevozi. Da bi se izvršio prijevoz između dviju različitih zemalja, npr. EU i Turske, potrebno je imati sve dokumente koji prate robu i prijevoznika od točke A do točke B (CMR, račun robe, provoznu deklaraciju, CEMT ili dozvolu određene zemlje te ostale carinske isprave). Svi ti dokumenti jednako su važni kako bi roba mogla proći kroz određene granice i na kraju biti rascarinjena u zemlji svoga krajnjeg odredišta.

\section{1 Carinska konvencija o ATA karnetu za privremeni prihvat robe}

ATA karnet je jednostavan međunarodni carinski dokument koji se koristi za pojednostavljenje privremenog uvoza robe u stranu zemlju. Ovim carinskim dokumentom omogućen je privremeni uvoz određenih kategorija robe u carinsko područje svake zemlje koja je prihvatila Konvenciju o privremenom uvozu, bez popunjavanja nacionalnih carinskih isprava, plaćanja carine i PDV-a ili polaganja depozita, što inače slijedi u redovitom postupku za privremeni izvoz, odnosno uvoz. Izdavatelj ATA karneta je nacionalna gospodarska komora u zemlji potpisnici konvencije, a u Republici Hrvatskoj je to Hrvatska gospodarska komora. Republika Hrvatska prihvatila je Konvenciju o karnetu ATA u rujnu 1994. godine (www.hgk.hr, 20. 6. 2016.). 
Karnet se izdaje na propisanoj tiskanici koja se sastoji od zelenih korica i talona žute, plave i bijele boje. Na koricama se nalazi serijski broj, vrijeme važenja, popis zemalja u kojima će se karnet koristiti, podaci o jamcima te podaci o robi na koju se odnosi. Žuti taloni se koriste kod provođenja carinskog postupka u zemlji privremenog izvoza, plavi pokrivaju postupke u zemlji provoza, a bijeli u zemlji uvoza. Svi taloni su perforirani kako bi njihov gornji dio mogao ostati u karnetu, dok donji zadržavaju odgovarajuće carinarnice. Osoba koja putuje s karnetom naziva se zastupnik. Ona može biti prijevoznik ili neka druga osoba koju nositelj opunomoći.

Navedeni karnet omogućuje jednostavan privremeni uvoz uzoraka, stručne opreme ili robe namijenjene izložbama, kongresima, sajmovima, natjecanjima i slično na rok od najduže godine dana. Nakon isteka roka roba mora napustiti carinsko područje i vratiti se u zemlju polazišta u izvornom obliku.

Karnet se može izdati fizičkim i pravnim osobama sa sjedištem u zemlji izdavatelja karneta. Njime se koriste poslovni ljudi, trgovci, izlagači, arhitekti, filmski djelatnici, fotografi itd. Različita potrošna roba, hrana i piće, ne mogu biti pokriveni karnetom ATA.

\section{2 Carinska konvencija o međunarodnom prijevozu robe na osnovi karneta TIR}

Carinska konvencija o međunarodnom prijevozu robe na osnovi karneta TIR donijeta je u Ženevi 1975. godine (Zelenika, 2006:102). Sadrži propise koji uređuju nadzor i postupak nad cestovnim prijevoznim sredstvima, kontejnerima i robom koja se prevozi na temelju karneta TIR u svim vrstama prijevoza pod uvjetom da je jedan dio puta obavljen cestom. Nastoji ubrzati, pojeftiniti i pojednostaviti mjere carinskog nadzora robe u tranzitu. Naime, sva strana prijevozna sredstva i strana roba koja je u provozu carinskim teritorijem neke zemlje čine carinsku robu, stoga podliježu carinskom nadzoru prema propisima te zemlje. Takvi postupci carinskog nadzora usporavaju promet i povećavaju troškove prijevoza te su se upravo navedenom konvencijom željele spriječiti takve poteškoće.

Karnet TIR (fr. Transport International pour la Rout) je carinska isprava za robu koja se prevozi teretnim vozilom. Funkcionira tako da pojednostavnjuje i usklađuje administrativne formalnosti u području međunarodnog prijevoza od polazne do odredišne carinarnice.

On je i svojevrsno jamstvo nekog osiguratelja carinskim vlastima tranzitnih zemalja kako će sva carinska davanja zajedno sa zateznim kamatama biti plaćena dođe li do nekih nepravilnosti u postupanju s karnetom TIR (Zelenika, 2006:102).

Samo funkcioniranje prijevoza temeljem karneta TIR počiva na određenim načelima. Prvo načelo podrazumijeva upotrebu vozila koja zadovoljavaju konstrukcijske uvjete navedene u nastavku rada, odnosno prijevoz robe u adekvatnim plombiranim vozilima ili kontejnerima. Sljedeće se načelo temelji na međunarodnom lancu jamstava. U svakoj državi kroz koju teret prolazi moraju postojati nacionalne jamstvene udruge koje je odobrila carinska uprava pojedine države, koja će pokriti eventualne carinske i druge pristojbe u slučaju zlouporabe. Nadalje, sve carinske vlasti zemalja kroz koje se odvija prijevoz priznaju karnet TIR kao kontrolnu ispravu, odnosno svi carinski postupci i mjere poduzeti u zemlji polazišta priznaju se i u tranzitnim i u zemlji odredišta. 
Da bi vozilo dobilo Uvjerenje o odobrenju za prijevoz pod carinskim obilježjem, ono mora biti konstruirano tako da omogući jednostavno stavljanje carinskih obilježja i provedbu carinskog pregleda cjelokupnog prostora. Ne smije biti omogućeno skrivanje robe u vozilu niti manipulacija robom nakon plombiranja vozila bez da ona ostavi vidne tragove povrede carinskih obilježja. Svaki pokušaj otvaranja ili pristupa unutrašnjosti kontejnera nakon stavljanja carinskih obilježja također mora biti jasno vidljiv.

Nakon ispunjenih navedenih uvjeta izdaje se Uvjerenje o odobrenju za prijevoz robe pod carinskim obilježjem, s rokom valjanosti od dvije godine, a na prednju i stražnju stranu vozila ili kontejnera stavlja se TIR pločica dimenzija 400 × 250 milimetara prikazana na slici 1 .

Slika 1. Označavanje vozila koje sudjeluje u provoznom procesu
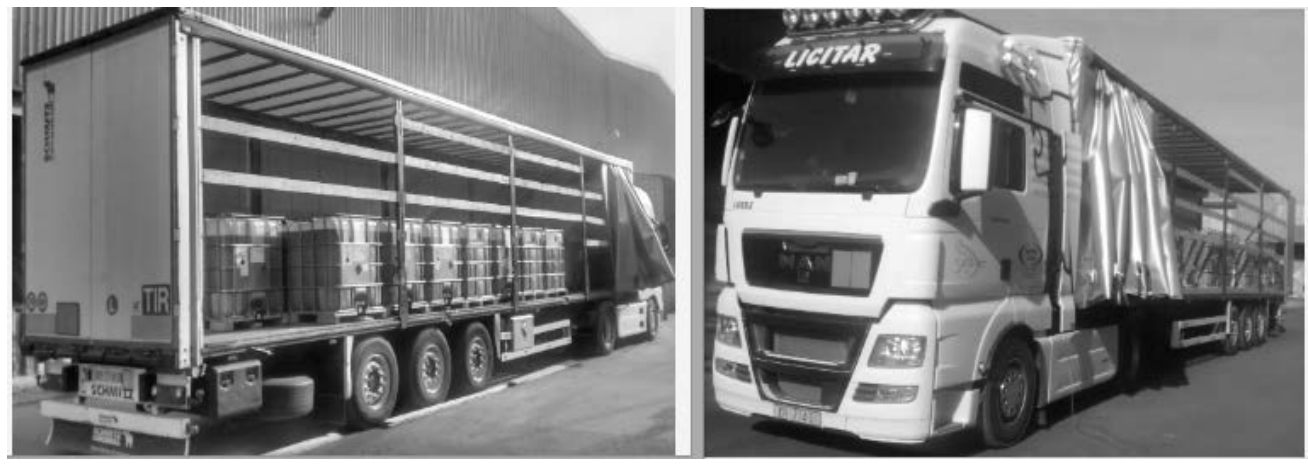

Izvor: fotografije autora

Karnet TIR omogućava da se sva ukrcana i carinski pregledana roba može prevoziti preko više državnih granica i teritorija bez carinskog pregleda i to od mjesta ukrcaja do mjesta u kojem se roba iskrcava. Navedeno bi trebalo omogućiti prijevoznicima kretanje preko državnih granica uz minimalna stajanja, čime bi se eliminirala eventualna kašnjenja i smanjili transportni troškovi. lako je carinski postupak za prijevoznika koji vozi na osnovi karneta TIR uvelike pojednostavljen, svi dokumenti su standardizirani i nema potrebe za ostavljanjem depozita na granicama tranzitnih država te rijetko dolazi do otvaranja plombiranih vozila. Sam se prolazak vozila kroz carinsku rampu obavi relativno brzo, ali ipak se ne može reći da karnet TIR osigurava kontinuiran ineometan prijevoz robe. Naime, s obzirom na to da ne postoje posebne trake niti carinske rampe za vozila koja prevoze robu na osnovi karneta $T I R$, ista se nalaze na prometnicima i u redu za carinsku rampu zajedno sa svim ostalim teretnim vozilima, što nerijetko dovodi do višesatnog stajanje u kolonama. Navedeno dovodi do troškova u vidu izgubljenih financijskih sredstva i vremena, no neizbježno i do stresa i nervoze kod samih vozača, a time i smanjenja sigurnosti u prometu.

\subsection{CMR konvencija o međunarodnom cestovnom prijevozu robe}

Konvencija o ugovoru u međunarodnom prometu robe cestom (fr. Convention relative au Contratdu Transport International de Marchandises par Route, CMR je standardni naziv) donijeta je 19. svibnja 1956. u Ženevi. CMR ili međunarodni tovarni list dokazuje da je roba napustila skladište dobavljača 
i bila preuzeta od strane prijevoznika i isporučena kupcu. Cilj ovog sporazuma bio je standardizirati postupke, prava i odgovornosti sudionika u prijevoznom procesu (Zelenika, 2006:96).

Odredbama CMR konvencije definirana je odgovornost vozara u slučaju gubitka ili oštećenja robe ili kašnjenja u isporuci, ali i u slučaju propusta njegovih predstavnika i drugih osoba čijim se uslugama koristio u obavljanju prijevoza te odnosi više cestovnih prijevoznika koji obavljaju prijevoz po jednom ugovoru. Odredbe se također odnose i na zaključenje ugovora o prijevozu te rokove zastarjelosti prava za pokretanje postupka u slučaju gubitka ili oštećenja robe.

CMR teretni list predstavlja ugovor između cestovnog prijevoznika i korisnika prijevoza. Teretni list popunjava pošiljatelj ili međunarodni špediter. Prilikom preuzimanja robe prijevoznik je dužan utvrditi točnost podataka navedenih u teretnom listu i to naročito broj koleta, oznake na ambalaži, vrstu ambalaže i vanjski izgled robe. Teretni list sastoji se od 3 dijela. Prvi dio ostaje kod pošiljatelja, drugi prati pošiljku, a treći zadržava prijevoznik.

Prema prijevozu na temelju CMR lista utvrđeno je (Zelenika, 2006:96):

- da je roba na cijelom prijevoznom putu pod carinskim nadzorom;

- carinski pregledi vrše se na izlaznoj, prolaznoj i ulaznoj carini;

- $\quad$ prijevoz se obavlja uz obavezno korištenje CMR teretnog lista;

- pošiljatelj tereta dužan je organizirati ili izvršiti utovar tereta ako drugačije nije ugovoreno;

- $\quad$ primatelj tereta dužan je organizirati ili izvršiti istovar;

- $\quad$ prijevoznik tereta dužan je izvršiti prijevoz u skladu s dogovorenim vremenom, relacijom i tarifom (prijevoz plaća pošiljatelj, ako se drugačije ne ugovori);

- u slučaju spora između stranaka u prijevozu može se dogovoriti nadležnost suda, ako se ne dogovori nadležan je sud koji određuje Međunarodna udruga cestovnih prijevoznika (IRA).

CMR se sastoji od 7 međusobno povezanih listova na kojima piše kome od sudionika transportnog procesa treba ići koji primjerak. CMR list obuhvaća sve podatke od mjesta gdje se roba preuzima, odnosno utovaruje na vozilo do mjesta istovara, uključujući informacije o prijevozniku robe, robi koja se prevozi (količina, težina, vrsta) i na koncu informacije o primatelju iste.

\subsection{CEMT/ECMT dozvola}

»CEMT dozvola« je multilateralna dozvola koju izdaje Europska konferencija ministara za promet, a na temelju koje je dopušteno obavljanje međunarodnog prijevoza tereta između država članica International Transport Foruma - ITF-a ili u tranzitu preko državnog područja jedne ili više država članica CEMT-a vozilima koja su registrirana u jednoj od država članica CEMT-a. Na temelju CEMT dozvole dopušteno je obavljanje neograničenog broja vožnji u određenom vremenskom razdoblju (godini, mjesecu), a opremljena je pripadajućim dnevnikom putovanja (http://www.propisi.hr/, 2. 7. 2016.). 
Postoje četiri vrste CEMT dozvola, a to su: austrijska, talijanska, grčka i CEMT dozvola za treće zemlje ili tzv. šuplji (drveni) CEMT. Austrijske, talijanske i grčke CEMT dozvole vrijede samo na tlu tih država, odnosno, za utovar, istovar i tranzit u tim državama, dok se za ostale države za koje su potrebne dozvole koristi šuplji CEMT (navedeno se odnosi na teretna vozila registrirana u RH).

\subsection{Europski sporazum o prijevozu opasne robe cestom (ADR)}

Transport, odnosno promet opasne robe (stvari, tvari, materijalnih dobara) u međunarodnom cestovnom prometu regulira se pravilima Europskog sporazuma o prijevozu opasne robe cestom (fr. Accord europeen relatif au transport international des marchandises dangereuses par route ADR, engl. Europen Agreement concerininig the Internationl carriage of of dangerous goods by road ADR) iz 1957. godine (Zelenika, 2006:97).

Opasnim tvarima smatraju se sve tvari koje mogu ugroziti ljudski život, nanijeti štetu ili zagaditi okoliš, a prema sporazumu ih se može razvrstati u devet klasa:

Klasa 1 - eksplozivne tvari i predmeti s eksplozivnim tvarima

Klasa 2 - plinovi

Klasa 3 - zapaljive tekućine

Klasa 4.1 - zapaljive krute tvari, samoreaktivne tvari i kruti desenzibilizirajući eksplozivi

Klasa 4.2 - tvari podložne spontanom samozapaljenju

Klasa 4.3 - tvari koje u dodiru s vodom stvaraju zapaljive plinove

Klasa 5.1 - oksidirajuće tvari

Klasa 5.2 - organski peroksidi

Klasa 6.1 - otrovne tvari

Klasa 6.2 - infektivne tvari

Klasa 7 - radioaktivni materijal

Klasa 8 - nagrizajuće (korozivne) tvari

Klasa 9 - ostale opasne tvari i predmeti.

Sam sporazum kratakjei jednostavan, a potpisan je s ciljem povećanja sigurnosti u međunarodnom cestovnom prijevozu. Sporazum se sastoji od dva dodatka. Dodatkom A propisane su odredbe koje se odnose na pakiranje i označavanje opasnih tvari listicama opasnosti, a dodatak B sadrži uvjete koje se odnose na konstrukciju, opremu i operacije koje se provode u vozilu namijenjenom prijevozu opasnih tvari. Dodaci se revidiraju i nadopunjuju svake dvije godine. Nova se dopuna očekuje u 2017. godini.

Svako vozilo u kojem se prevoze ADR-paketi mora biti odgovarajuće označeno kako bi svi sudionici na cesti uočili da je u vozilu opasan teret. Takva vozila podliježu i posebnom inspekcijskom nadzoru na cesti koji provodi prometna inspekcija. Pravila propisuju da se vozilo koje prevozi pakete s opasnim tvarima (bačve, kutije, plinske cilindre, IBC i sl.) mora označiti naprijed i odostraga praznom narančastom pločom obrubljenom crnim rubom, dimenzija $40 \times 30 \mathrm{~cm}$ (vidi sliku 1). 


\subsection{Vrste provoznih deklaracija}

Postoji više vrsta provoznih deklaracija pomoću kojih se obavlja prijevoz carinske robe. Najčešće se te deklaracije označavaju slovom T (npr. T1, T2, TIR...). Svaka od tih deklaracija koristi se na drugačiji način, te ima svoje prednosti i nedostatke, odnosno drugačije procedure tijekom provoza.

Roba u postupku provoza može imati dva statusa. Status Zajednice (engl. EU goods) ima roba koja je u cijelosti dobivena na području Zajednice (Europske unije) i nema dodataka robe iz trećih zemalja, roba koja je na području Zajednice proizvedena od dobara koja dolaze izvan teritorija Zajednice ili ona roba koja dolazi iz trećih zemalja, ali je puštena u slobodan promet u zemlji članici. Preostala roba nema status robe zajednice. Provoz svih vrsta roba u međunarodnom transportu na teritoriju ili izvan teritorija Europske unije moraju pratiti određene provozne deklaracije.

Tablica 1. Prednosti i nedostaci provoznih deklaracija

\begin{tabular}{|c|l|l|}
\hline $\begin{array}{c}\text { Vrsta } \\
\text { deklaracije }\end{array}$ & \multicolumn{1}{|c|}{ Prednosti } & \multicolumn{1}{|c|}{ Nedostaci } \\
\hline T1 & $\begin{array}{l}\text { najmanji troškovi provozne } \\
\text { deklaracije u određenim } \\
\text { situacijama }\end{array}$ & $\begin{array}{l}\text { zadržavanje na granicama radi izrade prateće } \\
\text { deklaracije kroz određenu državu i stalna } \\
\text { rendgenska kontrola na granicama }\end{array}$ \\
\hline T2 & $\begin{array}{l}\text { najpovoljnija cijena bez obzira } \\
\text { na vrijednost robe (40 eura), } \\
\text { brz prolaz kroz granice }\end{array}$ & $\begin{array}{l}\text { tijekom obavljanja prijevoza temeljem } \\
\text { provozne deklaracije T2 autor nije utvrdio } \\
\text { nepravilnosti koje su ometale prijevozni proces }\end{array}$ \\
\hline TIR karnet & $\begin{array}{l}\text { nema zadržavanja na granicama } \\
\text { radi izrade prateće deklaracije } \\
\text { kroz određenu državu }\end{array}$ & $\begin{array}{l}\text { najviša cijena (175 eura), mogućnost gubljenja } \\
\text { dokumenta zbog njegovog zadržavanja na } \\
\text { carini nakon istovara (7 dana) }\end{array}$ \\
\hline
\end{tabular}

Izvor: izradili autori

T1 - vanjski skupni provoz je osnovni provozni postupak EU-a koji se obično koristi za stranu robu. Vanjski skupni provoz omogućuje kretanje od jednog do drugoga kraja unutar istog carinskog područja: omogućuje odlaganje plaćanja carinskih davanja dok roba ne pristigne do odredišne carinarnice u EU-u. Vanjski skupni postupak nije dozvoljen, ako se roba kreće preko treće države, ali se može izvesti u slučaju da se provoz odvija cijelo vrijeme na osnovi jedinstvenog provoznoga dokumenta koji je izdan u EU-u i postupak se u trećoj državi privremeno prekine. Pri izlasku iz EU-a potrebno je podnijeti obavijest o prelasku granice i pri ponovnom ulasku u EU taj dokument ponovo podnijeti. U određenim slučajevima vanjski skupni provoz obavezan je i za robu EU-a, koja će biti izvezena u države EFTA-e $e^{5}$ ili preko država EFTA-e, na primjer, kad izvoz određene robe mora biti službeno nadziran (npr. izvozna kompenzacija). U tim slučajevima je uvođenje vanjskog provoznog postupka obavezno. Ako se ta roba izvozi preko drugih država EU-a, za potrebe nadzora upotrebljava se T5 (Rnjak, 2011:9).

5 Europska slobodna trgovinska zona (engl. European Free Trade Association) obuhvaća slobodnu razmjenu robe na području četiriju zemalja članica: Islanda, Lihtenštajna, Norveške i Švicarske. 
T2, T2F - unutarnji skupni provoz upotrebljava se za robu EU-a kada je ona poslana s jednog kraja, na području EU-a, na drugi preko trećih država, obično preko država EFTA-e, a da pritom roba ne izgubi status domaće robe. Taj provozni postupak nije obavezan, iako se preporučuje da se zadrži status robe. Treća područja određuje 6. smjernica EU-a ili direktiva 77/388/EEC. lako su ta područja dio carinskog područja EU-a, za njih vrijede posebni režimi obračuna davanja i trošarina. Radi osiguranja nadzora davanja za robu koja je poslana na ta područja, provodi se unutarnji provozni postupak EU-a (T2F) ili se priloži dokument za dokazivanje statusa robe (s oznakom T2LF) (Rnjak, 2011:9).

Već je navedeno da je temeljna misija TIR karneta da u najvećoj mogućoj mjeri pojednostavi, ubrza i olakša kretanje robe pod carinskim nadzorom u međunarodnoj robnoj razmjeni te da pruži potrebnu carinsku sigurnost i jamstvo državama kroz koje se prevoze, odnosno tranzitiraju carinske pošiljke.

Svaka od navedenih deklaracija ( $T 1, T 2, T I R)$ ima svoje prednosti, a time i određene mane (tablica 1). Razlike su najbolje primjetne u samoj praksi kada se carinska roba, tj. kamion koji je prevozi zatekne na graničnim prijelazima.

Naravno da postoje razlike u cijeni između navedenih deklaracija. Najskuplja opcija jest TIR karnet čija je cijena 175 eura za jedan smjer od ishodišta do odredišta, dok T1 deklaracija ima varijacije u cijeni ovisno o vrijednosti robe te može dostići cijenu TIR karneta. Provozna deklaracija TIR karnet obično ima najveću cijenu jer bi trebala osigurati najjednostavniju opciju koja omogućuje najbrži prolaz robe kroz granice. Već je navedeno da to u praksi nije u potpunosti točno jer ne postoji odvojeni prometni trak i posebna carinska rampa koja bi omogućila robi čiji je prateći dokument TIR brži i jednostavniji provoz s manje zadržavanja. Osnovna cijena T1 deklaracije je 25 eura ako je vrijednost robe do 180.000 eura. Kada vrijednost robe premašuje tu svotu, cijena T1 deklaracije dostiže cijenu do 100 eura i više. Kada se roba prevozi na temelju T1 provozne deklaracije u svakoj državi kroz koju se prolazi potrebno je raditi popratne papire radi garancije koju zahtijeva carinska služba te iste države, a minimalna cijena garancije kod špedicije koja je izrađuje iznosi 20 eura. Ako je vrijednost robe veća, veća je i cijena garancije. Carinska služba na graničnim prijelazima zahtijeva rendgensku kontrolu robe, ako se ona provozi na osnovi T1 deklaracije. Samim time povećava se zadržavanje na granicama, a rendgenska kontrola ima štetne posljedice za vozača koji je neprestano izložen zračenju. Optimalna opcija jest T2 provozna deklaracija koja ima najprihvatljiviju cijenu od 40 eura bez obzira na vrijednost robe. Njezina glavna prednost je da prati robu od izvozne carinarnice do uvozne carinarnice (za razliku od T1 deklaracije) što znači da nije potrebno raditi dodatne popratne dokumente koji povećavaju troškove i vrijeme zadržavanja na granicama. T2 kao i TIR karnet ne zahtijeva stalnu rendgensku kontrolu osim ako postoji bilo kakva sumnja od strane carinske službe da bi se moglo raditi o nekim kriminalnim radnjama.

\section{INFORMATIZACIJA U MEĐUNARODNOJ RAZMJENI I PROMETU}

Automatizacija i informatizacija, kao jedan od pristupa promjenama poslovnih procesa podrazumijeva uvođenje informacijskih tehnologija ili gotovih programskih rješenja, integralnih informacijskih sustava. 
Informatizacija obuhvaća sve sudionike u međunarodnoj robnoj razmjeni i prometu. Zbog toga je vrlo značajno da sve zemlje i sudionici u prometu uvode i razvijaju informacijske tehnologije. Razvoj programskih rješenja prilagođenih postojećim poslovnim procesima u trgovini i prometu podložan je stalnim promjenama i poboljšanjima. Osim razvoja programskih rješenja u prometu, nužno je voditi računa o integraciji tih programa u zemlji i inozemstvu te na području Europske unije.

Kada se govori o međunarodnim konvencijama i sporazumima u međunarodnom cestovnom prijevozu robe, treba naglasiti da carinske službe u novije vrijeme ulažu velike napore u razvoj vlastitih informacijskih sustava.

Prvi je korak na putu prema „trgovini bez papira“ razvoj sustava carinskog deklariranja bez papira. Upravo je to jedan od razloga što suvremene službe sve više prihvaćaju koncept „e-carina", odnosno „carina bez papira", što znači široku primjenu informacijskih tehnologija radi automatizacije trgovine i carinskih procedura.

Elektronički sustavi mogu, naime, ubrzati procese i povećati djelotvornost, jer u carinskim postupcima uistinu znatno ubrzavaju provedbu postupaka. Stoga Europska komisija - uz pretpostavku da globalizacija i liberalizacija znače i velik rast obujma međunarodne trgovine, a da carinske službe ne iskorištavaju sve mogućnosti informatičkih tehnologija i nedostatno su usklađene s poslovnom praksom distribucijskih lanaca - zagovara veću primjenu informatičke tehnologije u provođenju carinskih postupaka u državama članicama, što se temelji na konceptu prethodne najave pošiljaka pri unosu na područje EU-a. Najave se dostavljaju elektronički, što omogućuje procjenu rizika i poduzimanje daljnjih mjera, ovisno o utvrđenoj vrsti rizika. Tako postupke na granicama provode carinske službe radi suzbijanja krijumčarenja, dok se postupke za zaštitu financijskih interesa prenosi u organizacijske jedinice carinske službe koje obavljaju poslove na cijelom carinskom području. Temeljni cilj koncepta „e-carina“ ili „carina bez papira“ jest da carinske službe različitih zemalja uspostave sustav elektroničke razmjene podataka, odnosno podnošenja elektroničke carinske deklaracije kad god je to obvezno.

Za potrebe razmjene podataka (dokumenata, poruka) između gospodarstvenika i carine $\mathrm{RH}$ razvijen je modul (tzv. "B2G Servis"6) koji koristi više carinskih aplikacijskih podsustava što koriste internet kao komunikacijsku infrastrukturu. B2G Servis je aplikacijski pristupnik u informacijski sustav carine RH i nudi osnovne usluge razmjene dokumenata. Svaki podsustav (NCTS, ECS, ICS...) dodatno definira detalje komunikacije između aplikacije gospodarstvenika i carinskog podsustava koji proizlaze iz poslovnih potreba. Na razini B2G servisa obavljaju se sljedeće usluge (NCTS 4.0, Upute za gospodarstvenike, Carinska uprava Republike Hrvatske, 2013:283):

- identifikacija i kontrola pristupa

- $\quad$ provjera digitalnog potpisa

- autorizacija zahtjeva

- usmjeravanje zahtjeva na aplikacijski podsustav (NCTS, ECS...).

B2G (engl. Business to Government) sustav je koji omogućava elektroničku razmjenu podataka i dokumenata među poslovnim subjektima, državnom upravom i javnim službama. 
Novi kompjutorizirani provozni sustav (NCTS) predstavlja elektronički sustav razmjene podataka koji zamjenjuje papirnu provoznu carinsku deklaraciju na području Zajednice, ali i u razmjeni s trećim državama.

\section{NOVI KOMPJUTORIZIRANI PROVOZNI POSTUPAK (NCTS)}

Roba koja se prevozi na relaciji između Europske unije i zemalja koje nisu njene članice, odnosno nije roba zajednice, podliježe carinskoj kontroli i ostalim popratnim carinskim procedurama koje su obvezne kako bi se cjelokupni proces prijevoza mogao obavljati bez poteškoća. Da bi se roba mogla kretati na takvoj relaciji potrebno je imati popratne dokumente (T1, T2, T2L, TIR karnet) bez kojih nije moguće izvršiti cjelokupni proces prijevoza robe od točke A do točke B. Pošiljatelj robe dužan je priložiti sve ostale popratne dokumente robe (ATR dokument kojim se dokazuje porijeklo robe, $C M R$, račun, otpremnu specifikaciju), kako bi carinska kontrola mogla omogućiti početak kretanja robe $\mathrm{k}$ njezinu cilju.

Jedan od uvjeta za ulazak Republike Hrvatske u Europsku uniju bio je i usklađenje provoznog postupa s europskim zakonodavstvom vezanim uz Carinsku uniju. Sve zemlje članice Konvencije o zajedničkom provoznom postupku' (zemlje članice Europske unije i zemlje EFTA-e) provozni postupak temelje na NCTS sustavu. Najnovija verzija NCTS sustava omogućuje upravljanje carinskim postupcima na svim carinarnicama (otpremnoj, odredišnoj i provoznoj) te upravljanje jamstvima i sustavom naplate. Zapravo, zaštićenim elektroničkim prijenosom podataka omogućava se odvijanje cjelokupnog provoznog postupka eliminirajući pri tom potrebu za tradicionalnom razmjenom papirnate dokumentacije. Jedini papirnati dokument koji i dalje prati robu je isprava TAD/TSAD ${ }^{9}$ koja služi kao ispis podataka deklaracije i nositelj je broja provoznog postupka $\left(M R N^{10}\right)$.

Prije detaljnije analize NCTS sustava potrebno je definirati neke od osnovnih pojmova koji se koriste u primjeni NCTS sustava te omogućuju njegovo nesmetano funkcioniranje unutar istog carinskog sustava (Rnjak, 2011:5):

- glavni obveznik je osoba koja pušta robu u provozni postupak i osigurava garanciju;

- povlašteni pošiljatelj je osoba (glavni obveznik) kojoj Carina omogućuje provedbu provoznog postupka i izvoz robe bez podnošenja robe i carinskih deklaracija otpremnoj carinarnici;

- povlašteni primatelj je osoba kojoj Carina dozvoljava uvoz robe direktno u vlastiti prostor bez podnošenja robe i kontrole na carinskoj ispostavi;

- otpremna carinarnica/ispostava - carinska ispostava koja zaprima deklaracije za puštanje robe u provozni postupak;

7 Zajednički provozni postupak označava postupak u kojem se robu pod nadzor nadležnih tijela prevozi od jedne carinarnice ugovorne strane do druge carinarnice iste ugovorne strane ili carinarnice neke druge ugovorne strane preko najmanje jedne granice (https://carina.gov.hr/UserDocslmages//dokumenti/Procedure/Naputci// NDoc_1076.pdf, 13. 1. 2017.)

$8 \quad$ Engl. New Computerised Transit System - novi kompjutorizirani provozni postupak.

9 Transit Accompanying Document / Transit Security Accompanying Document - isprava koja prati provoz robe

10 Movement Reference Number - podatak kojim se identificira pojedini provozni postupak u cijeloj Europi 
- odredišna carinarnica/ispostava - carinska ispostava kojoj treba dostaviti robu u provoznom postupku kako bi se isti mogao zaključiti;

- provozna carinarnica/ispostava -carinarnica na ulazu u državu potpisnicu Konvencije o zajedničkom provoznom postupku koja nije članica EU-a ili carinarnica na ulazu u EU, u slučaju kad roba napušta državu potpisnicu Konvencije ili treću državu ili carinarnica na izlasku iz EU-a ili potpisnice Konvencije, kada pošiljka u provozu napušta carinsko područje te države potpisnice ili EU i ulazi u treću državu;

- $\quad$ garantni ured je ured koji nadležni organi svake države određuju, gdje obveznici polažu jamstva/garancije;

- $\quad$ središnja provozna carinarnica - nadređena otpremnoj carinarnici / nadređena odredišnoj carinarnici;

- $\quad$ redovit postupak / pojednostavljeni postupak-glavna razlika je u smještaju robe: kod redovitog postupka je roba koja kreće u ili završava provoz pod direktnim nadzorom carinske ispostave, dok je kod pojednostavljenog postupka roba u prostoru gospodarstvenika (povlaštenog pošiljatelja/primatelja). Pojednostavljeni postupak je moguć isključivo s dozvolom Carine;

- $\quad$ osiguranje carinskog duga - glavni obveznik mora osigurati garanciju za podmirenje carinskog duga ili drugih davanja, koja se mogu javiti vezano uz robu u provozu dok traje provozni postupak;

- $\quad$ zatvaranje provoznog postupka - dostavom robe odredišnoj carinarnici završava se prijevoz robe, završava provozni postupak i obveze glavnog obveznika nakon što carinski organ prekontrolira i evidentira robu (npr. kontrola carinskih plombi).

S ciljem usklađenja s europskim zakonodavstvom u Republici Hrvatskoj razvijena je nacionalna provozna aplikacija (NTA ${ }^{11}$ ) koja podržava sve funkcionalnosti NCTS sustava te od kolovoza 2011. omogućuje ostvarenje neprekinutog postupaka provoza robe pod carinskim nadzorom u Republici Hrvatskoj.

Prilikom poslovanja putem servisa e-carina svakom se gospodarstveniku dodjeljuje TIN broj od 17 znamenki ${ }^{12}$ koji ga jednoznačno predstavlja kao klijenta koji posluje s carinom putem servisa e-carina i kao takav predstavlja ovlaštenog primatelja ili pošiljatelja poruka u sustavu.

Cjelokupni proces provoza robe koji se obavlja putem NCTS sustava podijeljen je u dva dijela: prvi opisuje postupke pri otpremi robe u provoz, drugi dio postupke pri uvozu i pri zatvaranju postupka provoza. $U$ oba dijela se upute odnose kako na redovit tako i na pojednostavljene postupke provoza robe.

S obzirom na to da se komunikacija odvija elektroničkim putem omogućeno je pravodobno obavještavanje svih sudionika (prijevoznika, Carinske uprave RH i carinskih administracija na ruti prijevoza) o tijeku provoznog postupka, što osigurava pravilnu provedbu provoznog postupka i nesmetano kretanje pošiljaka od polazišta do odredišta, odnosno brži protok robe uz povećanje sigurnosti i smanjenje troškova.

11 Engl. National Transit Application - nacionalna provozna aplikacija

12 Prve dvije znamenke čine ISO alfa dvoznamenkasta šifra države (RH). Idućih 11 mjesta zauzimaju brojčane oznake OIB-a gospodarstvenika. Posljednja 4 mjesta predstavljaju nule. (Upute za gospodarstvenike, Carinska uprava RH, 2013) 
Shema 1. Razmjena poruka među sudionicima u provoznom postupku

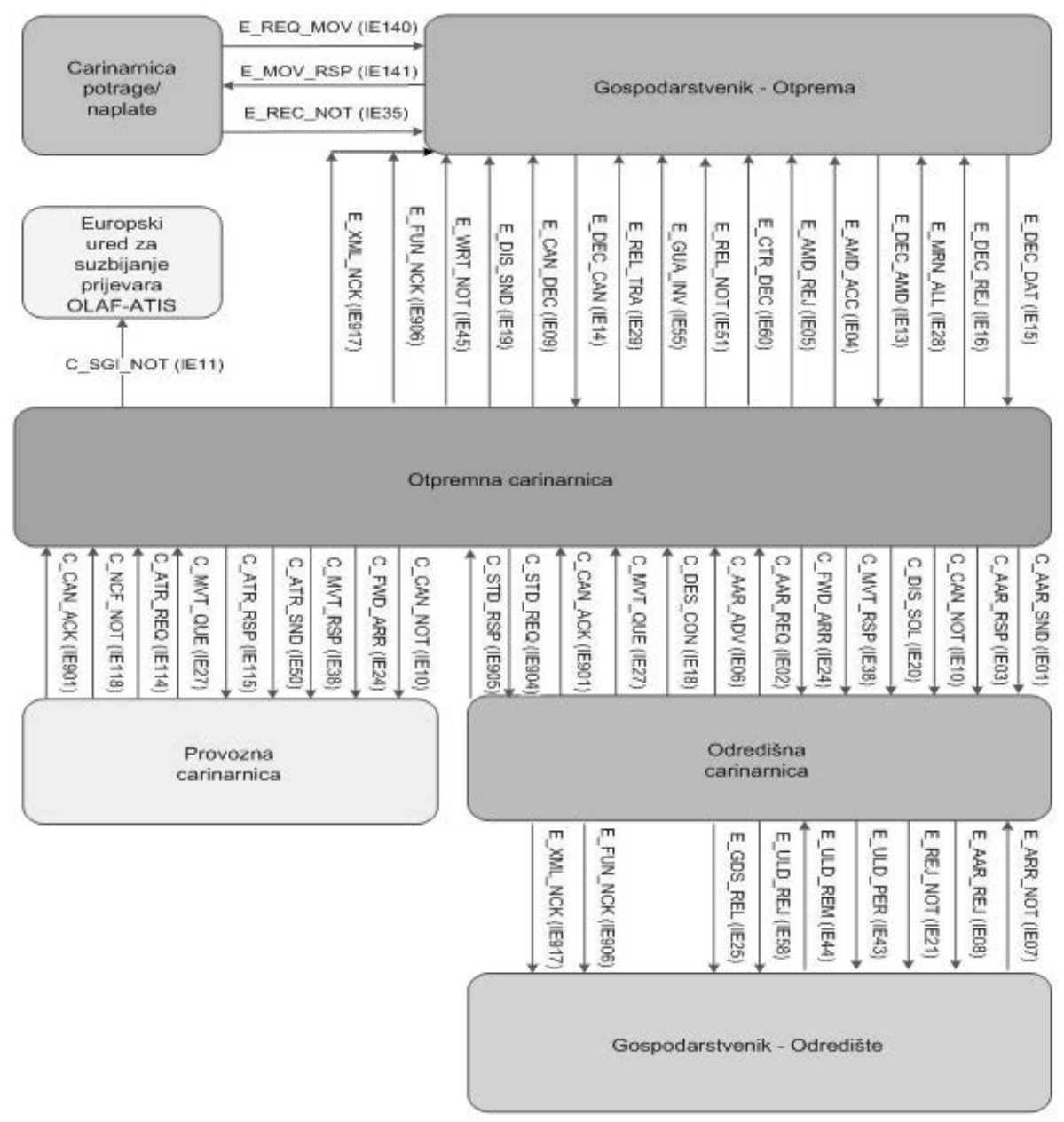

Izvor: Carinska uprava Republike Hrvatske (2013:8), NCTS 4.0, Upute za gospodarstvenike

Iz sheme 1 vidljivo je da su svim porukama koje se razmjenjuju između sudionika provoznog postupka dodijeljene odgovarajuće šifre ${ }^{13}$ čija su kratka objašnjenja navedena u nastavku rada dok se detaljnija mogu pronaći u NCTS 4.0, Uputama za gospodarstvenike koje je 2013. izdala Carinska uprava Republike Hrvatske (p. 9-16):

\section{postupak na otpremnoj carinarnici - prihvat i kontrola:}

- IE015 - podaci o deklaraciji je osnovna poruka koju vanjski korisnik šalje carinskom sustavu i predstavlja provoznu deklaraciju u elektroničkom obliku,

13 Svaka poruka ima svoj identifikator (npr. IE015), naziv (hrvatski: Podaci o deklaraciji, i engleski: Declaration data) i kratki naziv (E_DEC_DAT) (Upute za gospodarstvenike, Carinska uprava RH, 2013:23). 
- IE016 - deklaracija odbijena - ovom porukom se, u slučaju netočnih podataka deklaracije, odbija deklaracija glavnog obveznika prije prihvata, odnosno prije dodjele MRN broja,

- $\quad$ IE028 - dodijeljen MRN - ovom porukom carina dodjeljuje glavnom obvezniku broj provozne deklaracije MRN čime ga obavještava da je deklaracija prihvaćena,

- IE013 - zahtjev za izmjenom deklaracije - poruka koju vanjski korisnik šalje carinskom sustavu kao zahtjev za izmjenom već prihvaćene deklaracije kojoj je dodijeljen MRN, u redovitoj ili u pojednostavljenoj proceduri,

- $\quad$ IE004 - prihvaćanje izmjene deklaracije - poruka kojom carina odgovara glavnom obvezniku da prihvaća njegov zahtjev za izmjenom deklaracije,

- IE005 - odbijanje izmjene deklaracije - poruka kojom carina odgovara glavnom obvezniku da ne prihvaća njegov zahtjev za izmjenom deklaracije,

- IE060 - najava kontrole - ovom porukom obavještava se glavni obveznik o namjeri provedbe kontrole, odnosno pregleda robe,

- IE051 - odbijanje puštanja u provoz - u slučaju većih nepravilnosti ustanovljenih pri kontroli robe, ovom porukom obavještava se glavni obveznik da pošiljka ne može biti puštena u provoz,

\section{postupak u otpremnoj carinarnici - puštanje robe:}

- IE055 - neispravno jamstvo - u slučaju da je jamstvo neispravno (razlozi mogu biti: krivo upisan broj jamstva, neodgovarajući iznos, valjanost, nevaženje za pojedine zemlje), carinski sustav će poslati glavnom obvezniku obavijest u kojoj će mu biti naveden razlog odbijanja jamstva,

- IE029 - puštanje u provoz - carinski sustav obavještava glavnog obveznika o puštanju pošiljke u postupak provoza,

\section{postupak u otpremnoj carinarnici - poništenje:}

- IE014 - zahtjev za poništenjem deklaracije - glavni obveznik može zahtijevati poništenje deklaracije koja je već zaprimljena,

- IE009 - odluka o (ne)poništenju - ako carinski djelatnik odlučuje o poništenju deklaracije na temelju prethodnog zahtjeva glavnog obveznika, odluka može biti negativna ili pozitivna. Obje vrste odluka prosljeđuju se u poruci IE009,

\section{postupak u otpremnoj carinarnici - okončanje:}

- IE019 - nepravilnosti - otpremna ispostava obavještava glavnog obveznika da postoje nepravilnosti vezane uz njegovu pošiljku na odredištu i traži se od njega moguće pojašnjenje i ispravak tih nepravilnosti, što ih glavni obveznik može dojaviti alternativnim sredstvima komunikacije,

- IE045 - obavijest o razduženju - otpremna ispostava obavještava glavnog obveznika o razduženju provoznog postupka. U slučaju ispravno završenog provoznog postupka oslobađa se rezervirani iznos jamstva za tu pošiljku. Navedenom porukom okončava se postupak provoza, 


\section{postupak na odredišnoj carinarnici:}

- IE007 - gospodarstvenikova obavijest o dolasku - gospodarstvenik obavještava carinu o prispijeću pošiljke na odredište,

- IE008 - odbijanje gospodarstvenikove obavijesti o dolasku - ako je najava pošiljke na odredišnu ispostavu ili na lokaciju ovlaštenog primatelja neispravna, odnosno ako ne zadovoljava kriterije formalne i logičke provjere, šalje se poruka IE008 s razlogom odbijanja,

- IE021 - odbijanje najave očekivanog dolaska - carina obavještava primatelja da ne prihvaća prispijeće ili preusmjerenje pošiljke na ovu odredišnu ispostavu ili na lokaciju ovlaštenog primatelja,

- IE043 - dopuštenje za istovar - koristi se samo u slučaju pojednostavnjenog postupka kod ovlaštenog primatelja; ta poruka znači dozvolu za početak istovara,

- IE044 - bilješke o istovaru - ovlašteni primatelj odgovora na prethodno poslanu poruku IE043, kojom mu je odredišna ispostava dozvolila istovar, odnosno šalje obavijest o završetku istovara,

- IE058 - odbijanje bilješke o istovaru - NCTS sustav odbija bilješke o istovaru koje je poslao ovlašteni primatelj porukom IE044 s obrazloženjem odbijanja,

- IE025 - obavijest o puštanju robe gospodarstveniku - ova poruka dozvoljava puštanje robe iz postupka provoza.

\section{postupak potrage:}

- IE140 - zahtjev za informacijama o nepristigloj pošiljci - ovom se porukom zahtijeva od glavnog obveznika da, ako ih posjeduje, dostavi informacije o vlastitoj pošiljci koja nije stigla na odredište,

- IE141 - informacije o nepristigloj pošiljci - u slučaju prethodno poslanog zahtjeva za informacijama o nepristigloj pošiljci, porukom IE141 glavni obveznik šalje odgovor na taj zahtjev,

postupak naplate - porukom IE035 (obavijest o naplati) carina obavještava glavnog obveznika da je pokrenut postupak naplate po predmetnoj pošiljci,

\section{poruke o pogreškama:}

- IE906 - funkcionalna pogreška - poruka kojom se gospodarstvenika obavještava o činjenici da njegova prethodno poslana poruka nije logički ispravna i ne zadovoljava kriterije prema strukturnim pravilima i uvjetima te tehničkim pravilima,

- IE917 - pogreška u XML strukturi - poruka kojom se gospodarstvenika obavještava o činjenici da poruka koju je poslao nije formalno ispravna (ne zadovoljava XML shemu).

Analiza poruka zorno prikazuje da nacionalna provozna aplikacija omogućuje razmjenu informacija između prijevoznika i Carinske uprave koja zatim sve potrebne podatke prosljeđuje carinskim administracijama zemalja kroz koje se vrši prijevoz robe. Da bi sustav funkcionirao, sve provozne aplikacije vanjskih korisnika moraju generirati poruke čija je struktura i sadržaj kompatibilan s NTA aplikacijom kojom je Carinska uprava Republike Hrvatske uključena u NCST sustav. Sustav 
omogućava ubrzavanje cjelokupnog provoznog postupka, eliminira uporabu nepotrebne papirnate dokumentacije, ali i omogućava brzo uočavanje eventualnih pogrešaka te njihovo efikasno uklanjanje.

Tablica 2. Struktura LRN broja

\begin{tabular}{|c|l|c|c|}
\hline Polje & \multicolumn{1}{|c|}{ Sadržaj } & Tip polja & Primjer \\
\hline 1 & Osobni identifikacijski broj gospodarstvenika & Brojčano 11 & 12345678901 \\
\hline 2 & $\begin{array}{l}\text { Posljednje dvije znamenke godine podataka } \\
\text { provozne deklaracije (GG) }\end{array}$ & Brojčano 2 & 11 \\
\hline 3 & $\begin{array}{l}\text { Jedinstvena identifikacijska oznaka za provoznu } \\
\text { pošiljku po godini i gospodarstveniku }\end{array}$ & Brojčano 9 & 000000001 \\
\hline
\end{tabular}

Izvor: Carinska uprava Republike Hrvatske (2013:280), NCTS 4.0, Upute za gospodarstvenike

Postupak provoza započinje kada glavni obveznik, odnosno osoba koja ili u čije se ime šalje zajednička provozna deklaracija, deklaraciju elektroničkim putem pošalje informacijskom sustavu carine. Prilikom slanja deklaracije svaki korisnik svojoj pošiljci, u dogovoru s nadležnim tijelima, dodjeljuje lokalni referentni broj koji se sastoji od 22 znamenke opisane u tablici 2 (LRN broj) i koji jednoznačno predstavlja pošiljku do trenutka dodjele MRN broja, nakon čega on prestaje važiti.

Slika 2. Osnovni podaci o deklaraciji




MRN (referentni broj provoznog postupka) je ključni element NCTS-a. To je jedinstveni broj koji dodjeljuje carinski informacijski sustav nakon zaprimanja pravilno ispunjene i predane provozne deklaracije. MRN broj od 18 znamenaka (tablica 3 ) jedinstveno označava svaku pošiljku robe u provozu. Ako je MRN broj dodijeljen, svaka carinska ispostava, povezana u NCTS sustav, bilo gdje u Europi ima dostupne podatke carinske provozne deklaracije i može provesti kontrolu nad provozom, bez obzira na to, je li ili nije deklarirana kao odredišna carinarnica ili kao provozna ispostava.

Osnovne podatke o deklaraciji upisuje špediter na osnovi izvoznog papira (EU/EX papir), računa robe i CMR-a. Špediter na temelju tih papira robu uvodi u NCTS sustav preko kojeg dobiva MRN broj te vozaču izdaje osnovne podatke o deklaraciji (slika 2). $S$ tim dokumentom vozač ide na izlaznu carinarnicu te tamo dobiva provoznu deklaraciju (u ovom slučaju T2) nakon čega se vrši kontrola i plombiranje vozila koje se zatim upućuje do krajnjeg odredišta, tj. uvozne carinarnice.

Tablica 3. Struktura MNR boja

\begin{tabular}{|c|l|c|c|}
\hline Polje & \multicolumn{1}{|c|}{ Sadržaj } & Tip polja & Primjer \\
\hline 1 & $\begin{array}{l}\text { Posljednje dvije znamenke godine formalnog } \\
\text { odobrenja provozne deklaracije (GG) }\end{array}$ & Brojčano 2 & 11 \\
\hline 2 & $\begin{array}{l}\text { Oznaka zemlje u kojoj započinje provozni } \\
\text { postupak (ISO alfa 2 šifra zemlje) }\end{array}$ & Slovno 2 & HR \\
\hline 3 & Šifra otpremne carinarnice & Brojčano 6 & 041114 \\
\hline 4 & $\begin{array}{l}\text { Oznaka vrste postupka (T za provoz) } \\
\text { Jedinstvena identifikacijska oznaka za provoznu } \\
\text { pošiljku po godini i carinarnici }\end{array}$ & Brojčano 6 & Tlovno 1 \\
\hline 6 & Kontrolni broj & Slovno-brojčano 1 & 5 \\
\hline
\end{tabular}

Izvor: Carinska uprava Republike Hrvatske (2013:281), NCTS 4.0, Upute za gospodarstvenike

Postupak završava kada odredišna ispostava pošalje, također elektroničkim putem poruku otpremnoj carinarnica da je pošiljka uredno stigla na odredište. Glavni obveznik zatim, putem informacijskog sustava, bude obaviješten o okončanju provoznog postupka. 


\section{ZAKLJUČAK}

Analizirajući sve navedeno u ovom radu može se zaključiti da međunarodne konvencije i sporazumi te dokumentacija i procedure čine značajno područje i podlogu za obavljanje prijevoza robe $u$ međunarodnom cestovnom prijevozu.

S obzirom na to da se cestovni prijevoz posljednjih desetljeća razvija intenzivno i brzo, sukladno međunarodnoj trgovini i suvremenim tehnologijama prijevoza, bilo je neophodno definirati procedure i carinske postupke na prijelazu iz jednog carinskog sustava u drugi.

Klasične procedure prijelaza granice i provjera dokumentacije nisu osiguravali brz, siguran i racionalan međunarodni prijevoz robe u cestovnom prometu. Odgovor na to trebalo je potražiti u novim kompjutorskim provoznim sustavima.

Sva strana prijevozna sredstva i strana roba koja je u provozu carinskim teritorijem neke zemlje čine carinsku robu, stoga podliježu carinskom nadzoru prema propisima te zemlje. Takvi postupci carinskog nadzora usporavaju promet i povećavaju troškove prijevoza te se upravo potpisivanjem prethodno opisanih konvencija (Carinska konvencija o ATA karnetu za privremeni prihvat robe, Carinska konvencija o međunarodnom prijevozu robe na osnovi karneta TIR, CMR konvencija o međunarodnom cestovnom prijevozu robe) i, sukladno tome, korištenjem raznih carinskih deklaracija, žele spriječiti takve poteškoće. Carinskim konvencijama nastoji se ubrzati, pojeftiniti i pojednostaviti mjere carinskog nadzora robe u tranzitu.

Carinske konvencije primjenjuju se na zemlje članice, odnosno zemlje koje su ratificirale međunarodne konvencije s ciljem da olakšaju i pojednostave međunarodni prijevoz robe iz jedne države u drugu. Konvencije su carinske isprave koje zamjenjuju ostale složene carinske dokumente i pojednostavljuju provoz. Ako ipak dođe do komplikacija i nezakonitih radnji propisane su sankcije koje se provode protiv narušitelja propisanih pravila.

Kako bi se izbjegle neželjene komplikacije osmišljeni su novi sustavi koji pospješuju i ubrzavaju procedure carinskog provoza. Jedan od njih je i NCTS, odnosno sustav za računalno vođenje svih postupaka provoza. On omogućuje elektroničko preuzimanje i slanje svih poruka potrebnih za provedbu provoznog postupka. NCTS omogućuje bržu provedbu postupaka, brže razduženje garancija, brži protok roba, smanjenje troškova i veću sigurnost (bolja zaštita od zlouporabe).

Postoji više vrsta provoznih deklaracija pomoću kojih se obavlja prijevoz carinske robe. Najčešće se te deklaracije označavaju slovom T (npr. T1, T2, TIR...). Svaka od tih deklaracija koristi se na drugačiji način, te ima svoje prednosti i nedostatke, odnosno, drugačije su procedure u toku provoza.

Istraživanja i analize u ovom radu, a posebice novi kompjutorski provozni sustav, ukazuju na značenje, optimalno korištenje i vrstu provoznih deklaracija koje smanjuju troškove i vrijeme zadržavanja vozila na graničnim prijelazima. Nije potrebno isticati da brzina, sigurnost i cijena predstavljaju osnovne prednosti suvremenih prijevoznih sustava. 


\section{LITERATURA}

Baričević, H. (2001) Tehnologija kopnenog prometa, Rijeka: Pomorski fakultet u Rijeci, Glosa d.o.o.

Carinska uprava Republike Hrvatske (2013), NCTS 4.0, Upute za gospodarstvenike

http://www.propisi.hr/ (2. 7. 2016.)

https://carina.gov.hr/UserDocsImages//dokumenti/Procedure/Naputci//NDoc_1076.pdf (13. 1. 2017.)

Licitar, A. (2016) Isprave i konvencije u međunarodnom cestovnom prijevozu (specijalistički završni rad), Rijeka: Veleučilište u Rijeci

Matić, B. (2004) Međunarodno poslovanje, Zagreb: Sinergija

Nikolić, G., Ćiković, S. (2007) „Uloga carinskog sustava u uključivanju Hrvatske u Europski prometni i gospodarski sustav“, Suvremeni promet, 27(1-2), p. 335-338

Rnjak, V. (2011) TLM-modul-3 NCTS, Zagreb

Zelenika, R. (2006) Pravo multimodalnog prometa, Rijeka: Ekonomski fakultet u Rijeci

www.hgk.hr (20.6.2016.) 


\title{
A NEW COMPUTERIZED TRANSIT PROCEDURE IN INTERNATIONAL ROAD TRANSPORT ${ }^{4}$
}

\begin{abstract}
International road transport encompasses the transport of goods between a minimum of two countries and, in addition to transport, it includes all accompanying communications and operations (such as loading, reloading, unloading, storing, packaging, etc.) necessary to carry out transport operations in due time. With the aim of making the flow of international road transport as simple as possible in and out of the European Union, bilateral and multilateral agreements and various conventions have been followed. However, market globalization and modern logistics, which demands transparency of the entire process of cargo transport, have led to the need for automation and informatization procedures necessary for cargo transit to be of the highest quality and to have the lowest level of expenses. The New Computerized Transit System (NCTS) represents an electronic system of data exchange that replaces the paper version of transit customs declaration in the area of the European Union, but also in exchange with third countries. The use of the system enables managing customs procedures at customs offices, insurances and a payment system, fast noticing and reacting to possible mistakes and increasing security in the exchange of information. With the aim of adjusting with European legislation, the national transit application has been devised in the Republic of Croatia, which supports all functionalities of the NCTS system, and since August, 2011 it has enabled the implementation of uninterrupted procedures of cargo transit under customs monitoring in the Republic of Croatia.
\end{abstract}

Keywords: NCTS, conventions, transit procedure

MA, Senior Lecturer, Polytechnic of Rijeka, Vukovarska 58, 51000 Rijeka, Croatia. E-mail: barbara.rudic@veleri.hr Student, Polytechnic of Rijeka, Vukovarska 58, 51000 Rijeka, Croatia. E-mail: antonio.licitar2@gmail.com Spec. Ing. Traff., Lecturer, Polytechnic of Rijeka, Vukovarska 58, 51000 Rijeka, Croatia. E-mail: erika.grzin@veleri.hr Received: 15 January 2017; Accepted: 1 March 2017 
